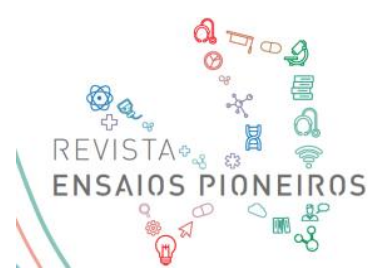

\section{ENSAIOS PIONEIROS}

Quando o Semesp projetou a organização das Redes de Cooperação não tínhamos a pretensão de obter bons resultados no curto prazo. As experiências nacionais e internacionais indicam que processos de cooperação precisam de tempo para que as instituições envolvidas adquiram confiança para trocarem informações estratégicas e compartilharem serviços e compras para, dessa forma, reduzirem custos. Em pouco mais de um ano já organizamos sete Redes de Cooperação, que reúnem 31 instituições de ensino superior.

Cada Rede tem seu perfil e uma dinâmica própria, o que é previsível. O que sustenta o funcionamento das Redes é a relação de confiança entre as pessoas e a percepção de que todas as instituições participantes são beneficiadas. A sensação de benefício por participar da Rede se intensifica a cada reunião e pode ser observada nas atitudes e nas afirmações dos dirigentes das IES.

Quando iniciamos o processo de organização das Redes convidamos instituições que desejavam participar da cooperação. No Semesp, tínhamos a convicção de que era necessário começar a experiência com instituições que tinham perfis semelhantes.

A primeira Rede logo se transformou em Rede Pioneira, formada pela USF Universidade São Francisco, UNIFEOB - Centro Universitário Octávio Bastos e UNIARARAS Centro Universitário Hermínio Ometto. O nome nasceu das próprias instituições, que com a maturidade adquirida com as reuniões criaram grupos de trabalho e descentralizaram a dinâmica da Rede. Os grupos de trabalho são formados por representantes de cada instituição e hoje são

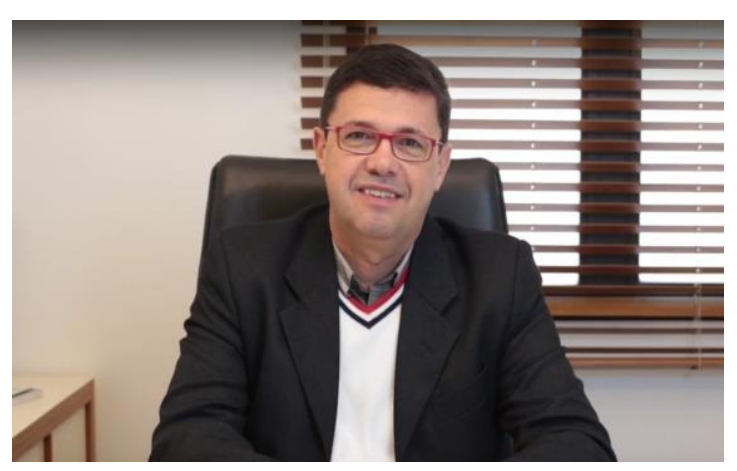

Fábio Reis

Diretor de Inovação Acadêmica e Redes de Cooperação

responsáveis por organizarem os projetos que, posteriormente, são aprovados pelos dirigentes das instituições.

O grupo de trabalho da dimensão acadêmica da Rede Pioneira propôs e foi aprovada a criação de uma revista acadêmica para as três instituições da Rede. A Revista Ensaios Pioneiros representa uma conquista do grupo. Não é comum IES organizarem publicações de forma coletiva.

A organização conjunta da Revista diminui custos, cria sinergia, amplia a discussão acadêmica, oferece oportunidade de publicação para os professores, cria a oportunidade das instituições realizarem pesquisa, projetos acadêmicos ou de extensão em conjunto e fortalece os vínculos institucionais. A publicação demonstra que a Rede Pioneira está no caminho certo. Nós do Semesp estamos felizes com a inciativa da Rede Pioneira.

Estamos certos de que a Rede Pioneira irá desenvolver outros projetos e que as iniciativas do grupo irão se transformar em exemplo de cooperação para as demais Redes. 